VIEWPOINT

\title{
Campaign Finance Reform as a Health Issue in the USA
}

\author{
Aditya K. Khetan, MD and Richard Josephson, MS, MD
}

University Hospitals Cleveland Medical Center, Case Western Reserve University, Cleveland, OH, USA.

J Gen Intern Med 35(7):2189-90

DOI: $10.1007 / \mathrm{s} 11606-020-05828-9$

(c) Society of General Internal Medicine 2020

$\mathrm{L}$ ife expectancy in the USA peaked in 2014, with a lower life expectancy in 2018 than in $2014 .^{1}$ No other highincome country has undergone a similar phenomenon since World War I, which points to the extraordinary circumstance that the USA finds itself in. While the rise of the opioid epidemic plays a role, it only explains about $20-25 \%$ of the increase in deaths. The remaining deaths stem from a combination of suicide, stroke, influenza, Alzheimer's, and liver disease. Deaths from some of these diseases have been rising since around 2000; however, their effects on overall life expectancy were offset by decades of steadily declining mortality from cardiovascular diseases. This decline in cardiovascular mortality is now plateauing, and it is the sum total of these trends that have caused life expectancy to start declining in the past few years. $^{2}$

The multiplicity of health conditions that are adversely affecting the health of Americans suggests that there may be common underlying factors that are driving this trend. Given the primacy of socioeconomic conditions in determining a nation's health, recent trends in socioeconomic conditions in the USA are worth examining for their relationship to life expectancy. ${ }^{3}$ Between 2001 and 2014, women in the top 5\% of the income distribution had an increase in life expectancy of 2.91 years, while women in the bottom $5 \%$ of the income distribution had an increase of only 0.04 years. A similar trend was true for men. ${ }^{4}$ In the same vein, while non-Hispanic whites with a college degree have continued to improve their life expectancy, non-Hispanic whites with a high school education or less have had a steady decline in life expectancy since the year 2000. There is a similar disparity in growth in household income that corresponds to this gap in growth of life expectancy between the top and bottom 5\% of the income distribution. Between 1985 and 2008, household income for the top decile grew at an annual rate 15 times than of the lowest decile ( $1.5 \%$ vs. $0.1 \%$ ). This gap was one of the highest amongst OECD countries and accompanied by the highest

Received October 25, 2019

Accepted March 27, 2020

Published online April 13, 2020
GINI index (a measure of income inequality) amongst highincome OECD countries. ${ }^{5}$ While the relationship between income inequality and decreasing life expectancy is likely causal, it is unclear to what extent this may be contributing to the decline in life expectancy. ${ }^{6}$

Given the adverse effects of income inequality on life expectancy, factors that lead to income inequality likely contribute to decline in life expectancy. Over the past few decades, a large driver of the wealth gap in the USA has been a rise in rent-seeking behavior. ${ }^{7}$ Rent seeking is an economic concept that describes efforts to increase one's share of the existing wealth of a nation without reciprocal contribution of productivity. Lobbying to obtain disproportionate tax credits or reductions, exclusive licenses, or monopolies are examples of rent-seeking activities. For instance, tax credits may benefit only large corporations (who spend money lobbying for the benefit), with no plausible benefit to society. Rent seeking is different from innovation and entrepreneurship in that it does not generate any new wealth for the economy. One category of rent seeking is regulatory capture, wherein regulatory agencies are dominated by the interests of the very industries they are tasked with regulating. An example of this is regulation passed by the Congress (Dickey Amendment) preventing the CDC from carrying out gun violence-related research. The amendment was the result of lobbying by the National Rifle Association (NRA) and resulted in effective regulatory capture, stymieing attempts at studying gun violence through federally funded research. Similar regulation has been passed by the Congress undercutting the Federal Aviation Administration's (FAA) role in regulating manufacturing of airplanes, resulting in regulatory benefit to Boeing, at considerable cost to public safety. Some of these costs are difficult to calculate and not immediately obvious and, in the case of Boeing, only came to the fore after deaths occurred as a result of problems with the Boeing 737 Max. ${ }^{8}$ Further examples of three major types of rent-seeking behaviors are summarized in Table 1. Growth of rent-seeking practices can lead to inefficient allocation of resources, impaired competition, growth of a powerful class of lobbyists, social unrest, and income inequality. In fact, income inequality can be both a consequence and a cause of further rent seeking.

With the rise of rent seeking, the relationship between those who seek rent and government officials (elected and nominated) has become stronger. The relationship thrives on mutually beneficial arrangements, with elected government officials increasingly dependent on rent seekers to raise money for their 
Table 1 Examples of Three Types of Rent-Seeking Behavior

\begin{tabular}{ll}
\hline \hline Rent-seeking behavior & Example \\
\hline Regulatory capture & $\begin{array}{l}\text { Lax gun laws, Medicare not being allowed } \\
\text { to negotiate drug prices, poor post market } \\
\text { surveillance of drugs and devices by the }\end{array}$ \\
$\begin{array}{l}\text { FDA } \\
\text { Barriers to entry of generic drugs, } \\
\text { Imposing regulations on } \\
\text { Lompetitors } \\
\text { Lobbying for }\end{array}$ & $\begin{array}{l}\text { Tax breaks, lobbying in states attempting to } \\
\text { remove sugar-sweetened beverages (SSBs) } \\
\text { from Supplemental Nutrition Assistance }\end{array}$ \\
& Program (SNAP) purchases \\
\hline
\end{tabular}

election campaigns. In 1990, a total of \$280 million was raised by candidates vying for a seat in Congress. That number rose to $\$ 1.7$ billion in the 2018 election cycle. Newly elected congressmen and congresswomen are often spending up to half their workday raising funds for the next election cycle. Given the large amounts of money people standing for election have to raise, it is not surprising that they become more vulnerable to rent-seeking practices. Breaking this financial relationship will make government less beholden to companies that seek rent and be a major step towards reducing inequality. It will allow government officials to spend more time on issues that matter to the electorate and pass regulations without fear or favor. Financial resources of the government that are spent on inefficient subsidies can be spent on housing, nutrition, education, and other social factors that have a large effect on life expectancy. The USA is currently the only western democracy that does not have any caps on either fundraising or spending for an election campaign. This unique position of elected US government officials makes them extraordinarily vulnerable to rent seeking, as they must raise and spend increasing amounts of money to be competitive for elected office.

Campaign finance reform that weakens the relationship between bodies that seek rent and government officials can restore the ability of government to enhance the health of all Americans. H.R. 1, passed by the US Congress in November 2018, primarily deals with campaign finance reform and strengthening conflict of interest laws. Laws such as these may be the key to improving life expectancy in the USA in the long term. Without campaign finance reform, the US government will likely continue to be beholden to rent seekers. And while short-term measures can help improve life expectancy in the near future, more fundamental changes in our socioeconomic arrangements will be needed to reverse the systemic decline of communities. While the road may seem winding, there is a trail from campaign finance reform to a recovery of life expectancy in the USA.

Corresponding Author: Aditya K. Khetan, MD; University Hospitals Cleveland Medical Center Case Western Reserve University, Cleveland, OH, USA (e-mail: axk757@case.edu).

Compliance with Ethical Standards:

Conflict of Interest: The authors have no conflicts of interest to disclose.

\section{REFERENCES}

1. Murphy SL, Xu J, Kochanek KD, Arias E. Mortality in the United States, 2018.

2. Case A, Deaton A. Mortality and morbidity in the 21 st century. Brook Pap Econ Act. 2017;2017(1):397-476.

3. Frieden TR. A framework for public health action: the health impact pyramid. Am J Public Health. 2010;100(4):590-5.

4. Chetty R, Stepner M, Abraham S, Lin S, Scuderi B, Turner N, et al. The association between income and life expectancy in the United States, 2001-2014. JAMA. 2016;315(16):1750-66.

5. Stand DW, Rising WIK. An overview of growing income inequalities in OECD countries: main findings. Divid We Stand Why Inequal Keeps Rising. 2011;

6. Pickett KE, Wilkinson RG. Income inequality and health: a causal review. Soc Sci Med. 2015; 128:316-26.

7. Deaton A. Where in the world is the world heading? J Policy Model. 2017;39(4):603.

8. After Boeing crashes, sharp questions about industry regulating itself-The New York Times [Internet]. [cited 2019 Dec 17]. Available from: https://www.nytimes.com/2019/03/26/us/politics/boeing-faa.html. Accessed 17 Dec 2019.

Publisher's Note: Springer Nature remains neutral with regard to jurisdictional claims in published maps and institutional affiliations. 